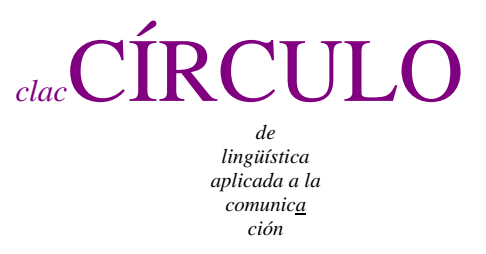

$63 / 2015$

\title{
ON THE USER'S SIDE: DEFINITIONS IN ITALIAN AND BRITISH PATIENT INFORMATION LEAFLETS
}

\author{
Patrizia Pierini \\ Università degli Studi Roma Tre \\ patrizia pierini at uniroma3 it
}

\begin{abstract}
This article examines patient information leaflets (PILs), as texts addressed by experts to laypersons. The PIL (foglio illustrativo in Italian) is a mandatory document packed with medicines that provide the patient with information about the medicine and instructions on how and when to take it. The paper comparatively analyses the definitions of medical terms in Italian and British PILs. It is based on a qualitative analysis of data extracted from two small comparable corpora consisting of 50 Italian and 50 British texts, respectively. Results have revealed some similarities that seem to be cross-cultural features of the genre, and significant differences.
\end{abstract}

Keywords: definitions, patient information leaflets, Italian, English.

Pierini, Patrizia. 2015.

On the user's side: definitions in Italian and British patient information leaflets

Círculo de Lingüística Aplicada a la Comunicación 63, 218-239.

http://www.ucm.es/info/circulo/no63/barcena.pdf

http://revistas.ucm.es/index.php/CLAC

http://dx.doi.org/10.5209/rev_CLAC.2015.v63.50176

(C) 2015 Patrizia Pierini

Círculo de Lingüística Aplicada a la Comunicación (clac)

Universidad Complutense de Madrid. ISSN 1576-4737. http://www.ucm.es/info/circulo 
Contents

1. Introduction 219

2. The patient information leaflet as genre 222

3. Defining 224

4. How to treat medical terms in PILs 227

5. Analysing definitions 229

5.1 Corpus compilation and methodology 229

5.2 Analysis of data 230

6. Discussion 234

7. Conclusions 236

References 237

\section{Introduction}

Medical discourse is a domain-specific language which has an increasing relevance and pervasiveness in contemporary society. It is realized in a number of spoken and written medical genres that are explored by linguists and professional communities around the world (Gotti \& Salager Meyer, 2006). Several are the genres addressed to experts, such as the research article, the case-report, the clinical case history, the post-mortem report (Maglie 2009: 41-75). But medicine is the science that like no other communicates with non-experts. There are three main reasons for this phenomenon. First, patients want to receive information about their condition and health care (Kenny et al., 1998). Second, prevention is a general concern in contemporary society, hence the relevance of health education. Third, medicine is in constant evolution, and mass media inform people about new developments in diagnostics, treatments and surgical procedures. 
As a result, various genres are addressed to the general audience or the interested reader - printed information materials on general health topics or common illnesses distributed by pharmacists or obtained by general practitioners, newspaper and magazine articles, TV programmes, and health websites. Then, there are the genres addressed to patients, such as the prescription and the patient information leaflet.

The patient information leaflet (PIL), foglio illustrativo in Italian, is a mandatory document written by the pharmaceutical manufacturer, which is packed with a medicine and provides the user information about that $\operatorname{drug}^{1}$. The pharmaceutical industry is a regulated industry in all its aspects, being subject to regulations established by European institutions. The PIL as well is tightly regulated on a European level by the European Medicines Agency (EMA), and locally by national competent authorities - the Medicines and Healthcare Products Regulatory Agency (MHRA) in UK, and the Agenzia Italiana del Farmaco (AIFA) in Italy. The aim is to guarantee an easily legible and clearly comprehensible text enabling patients to use the medical product safely and appropriately (European Commission 2009:5).

The EU regulations, while producing uniformity in content, format, headings, and standard wording for certain terms (EMA, 2011a, 2011b), do not guarantee leaflet usability $^{2}$. Official documents such as AIFA (2004) and MHRA (2005) draw the attention to the variable degree of comprehensibility of PILs, which frequently do not meet the patients' needs. Patients usually perceive PILs to be lengthy, difficult to understand for the technicality and the large amount of information piled up in a small leaflet, and not easily legible because printed in small font size on thin multiply folded paper. These documents also agree about the need for improving the quality of PILs, and the European Commission (2009) has provided guidelines on their readability.

\footnotetext{
1 There are differences in the naming of this genre in the literature. What we call PIL is designated as 'patient package insert' in Askehave \& Zethsen (2003) and Connor et al. (2008), while other scholars (e.g. Clerehan - Buchbinder 2006 , Kenny et al. 1998) call 'patient information leaflets' various types of informational materials for patients. In the British PILs examined (see section 2), we found PIL and 'package leaflet'.

2 By 'usability' we refer to both (linguistic) readability and (perceptual/visual) legibility, the latter depending on physical aspects (e.g. quality of paper) and typographic features (font type, font size, white space, bolding, bulleted lists, etc.).
} 
Similar observations are found in research, which has been carried out by health professionals and linguists. Studies focus on the reception of texts (e.g. Hirsh et al., 2009; Bernardini et al., 2001; Pander Maat \& Lentz, 2010) or on the texts themselves. For example, Askehave \& Zethsen (2003) have analysed the barriers to patient comprehension in PILs. From different perspectives, Clerehan \& Buchbinder (2006) and Garner, Ning \& Francis (2011) have elaborated approaches to evaluate texts that can provide insights for the improvement of materials. Connor et al. (2008) have compared rhetorical moves and vocabulary of American and Spanish PILs. In Italy, Serianni (2005:248-254) has highlighted the variability in PILs and their linguistic and textual shortcomings, and Puato (2012) has compared the linguistic features of Italian and German PILs.

Since they are addressed by experts to laypersons, PILs should be understandable texts with a low level of discourse specialization (Gotti 2005:25-27) in which the terms introduced are defined. The present article, which contributes to text-oriented research, is aimed at comparatively analysing the definitions of medical terms in Italian and British PILs. It is based on a qualitative analysis of data extracted from two small comparable corpora consisting of 50 Italian and 50 British texts, respectively. The collected texts show similarities in their macro features and differences in their micro features, ascribable to cultural differences — different national legal requirements, different national health services, different discursive practices ${ }^{3}$.

The paper is organised as follows: section 2 focuses on the PIL as genre; section 3 is devoted to defining; section 4 deals with how to treat medical terms in PILs; section 5 describes corpus compilation and methodology, and analyses the definitions extracted from selected sections of the texts; section 6 discusses the dominant trends identified in the corpora. Some conclusions are drawn in the final section.

\footnotetext{
${ }^{3}$ There are differences also in the dissemination of information about medicines in official websites. The Electronic Medical Compendium in UK (http://www.medicines.org.uk/emc) provides up-to-date and comprehensive information making available PILs and SPCs (Summery of Product Characteristics) of both prescription and non-prescription medicines to health professionals, patients and the general public. The Prontuario Farmaceutico Nazionale in Italy (http://www.prontuariofarmaceutico.it) provides the SPCs of prescription medicines only, and is addressed to health professionals.
} 
2. The patient information leaflet as genre

A general feature of the PIL is its brevity that characterises other small texts in medical communication, such as the prescription and the clinical case history (Cassandro 1994: 71-72). As suggested in genre theory (Bhatia, 2004), the first step is to identify textual and contextual features. The text producer is a body (the pharmaceutical company) and the intended receivers are the users of the medicine - a large and heterogeneous audience varying by age, education and background knowledge, that can be characterised as indeterminate and non-expert. The intended audience is indicated in the "opening” of some Italian texts and the majority of the British ones:

(1) a. Foglio illustrativo: informazioni per l'utilizzatore.

b. Informazioni per il consumatore.

(2) a. Patient information leaflet

b. Package leaflet: information for the user.

The "opening” can be followed by an "introductory recommendation” whose function is to recommend receivers specific courses of action, as in (3) and (4):

(3) a. Prima dell'uso leggete con attenzione tutte le informazioni contenute nel foglio illustrativo. Questo è un medicinale di AUTOMEDICAZIONE che potete usare per curare disturbi lievi e transitori facilmente riconoscibili e risolvibili senza ricorrere al medico. Può essere quindi acquistato senza ricetta medica, ma va usato correttamente per assicurarne l'efficacia e ridurre gli effetti indesiderati. Per maggiori informazioni e consigli rivolgetevi al farmacista.

b. Legga attentamente questo foglio prima di prendere questo medicinale. Conservi questo foglio. Potrebbe avere bisogno di leggerlo di nuovo.

- Se ha qualsiasi dubbio, si rivolga al medico o al farmacista.

- Questo medicinale è stato prescritto per lei personalmente. Non lo dia ad altri. Infatti, per altri individui questo medicinale potrebbe essere pericoloso, anche se i loro sintomi sono uguali ai suoi.

- Se uno qualsiasi degli effetti indesiderati peggiora, o se nota la comparsa di un qualsiasi effetto indesiderato non elencato in questo foglio, informi il medico o il farmacista.

(4) Read all this leaflet carefully before you start to take your medicine.

- Keep this leaflet. You may need to read it again. 
- If you have any further questions, please ask your doctor or pharmacist.

- This medicine has been prescribed for you. Do not pass it on to others. It may harm them, even if their symptoms are the same as yours.

- If any of the side effects gets serious or if you notice any side effects not listed in this leaflet, please tell your doctor or pharmacist.

(3a) only occurs in the leaflets accompanying a subtype of non-prescription medicines (see 'on advice' medicines in Note 4). (3b) is found only in some leaflets accompanying prescription medicines in the Italian corpus, while (4) occurs in all the PILs in the British corpus.

Although the name of the genre in both languages points to its informational nature (information in English, illustrativo in Italian), its predominant communicative purpose is to provide patients with instructions on how and when to take the medicine. The action(s) to be performed are in the interest of the receivers, who will follow the instructions by virtue of their practical consequences (benefits) and of the sender's expertise. It can be ascribed to the class of directive texts whose communicative purpose is to affect the receivers’ behaviour (Mortara Garavelli, 1988).

The PIL also has a subsidiary but not less relevant function, that of informing about the risks associated with the medicine. Potential risks are communicated mainly in the moves “contraindications”, “side effects”, “precautions for use”, “interaction with other drugs” (Table 1), according to the informed consent model inherited by surgery judicature (Osimani, 2007). So the PIL is also a means of risk prevention, and should result from a negotiation between the need for patients to access understandable information, and the need for pharmaceutical companies to provide detailed and technical information in order to avoid legal repercussions from possible lawsuits in the case of medical reactions (AIFA 2004:51).

Being subject to regulations, the PIL is a highly conventionalised genre at various levels—sender, communicative purpose, intended audience, content, textual structure, and graphological aspects. Its generic structure is illustrated in Table 1 presenting the potential moves and their functions as identified in our corpora.

TABLE 1. Generic structure of PILs 


\begin{tabular}{|l|l|}
\hline MOVE & FUNCTION \\
\hline opening & state purpose and intended audience \\
\hline introductory recommendation & recommend \\
\hline name of the medicine & inform \\
\hline pharmacotherapeutic group & define \\
\hline composition & inform \\
\hline pharmaceutical form & describe \\
\hline indications & inform \\
\hline posology and method of administration & instruct \\
\hline contraindications & warn, prohibit \\
\hline possible side effects & inform \\
\hline precautions for use & warn \\
\hline drug interactions & inform \\
\hline drug storage & instruct \\
\hline further information & inform \\
\hline manufacturer & inform \\
\hline marketing authorisation holder & inform \\
\hline date of revision of PIL & inform \\
\hline
\end{tabular}

\section{Defining}

Defining is one of the basic speech acts placed by Searle (1975) in the class of 'representatives', with claiming, stating, describing, arguing. Definitions are rare in everyday communication, but are frequent in scientific and technical discourse, where defining is a relevant activity along with classifying, describing, generalising and exemplifying.

A definition is a statement that clarifies the meaning of a term in the immediate context (Darian, 1982). It establishes an equation between term and concept: $\mathrm{X}=\mathrm{Y}$, a sort of semantic equivalence where $\mathrm{X}$ (the term) is the definiendum, and $\mathrm{Y}$ is the definiens (its periphrasis). $\mathrm{X}$ and $\mathrm{Y}$ are joined by a 'relater', which can be a punctuation mark (comma, parentheses, dash, colon) or a linguistic item, such as a verb (be, refer to, consist of) or an expression (known as). The relater can be seen as the marker of 
definition. In the statement $A$ tetrahedron is a solid shape with four flat sides, a tetrahedron is the definiendum, a solid shape with four flat sides is the definiens, and the verb is is the relater. The resulting pattern is: $\mathrm{X}$ is $\mathrm{Y}$.

With regard to the semantics of definitions, experts search for some essential qualities/properties that define a term $\mathrm{X}$ and differentiate it from others. They can employ different methods referring to features such as class/category, function/use, parts/ingredients/contents, contrast or similarity, origin/source, behaviour, etymology, shape and colour.

With regard to pragmatic aspects, the function of a definition can vary across genres depending on their intended audience. In genres addressed to non-experts, its function is to explain the meaning of a word or expression that is (supposed to be) unknown to the reader. In genres addressed to experts, it can have other functions (Sager 1990:40): to redesignate the meaning of a lexical item for a specific purpose in discourse ('stipulative' function), or to fix the specialised meaning of a term.

Definitions, as products of the defining process, can vary by pattern, method and function depending on factors such as domain, genre, communicative purpose (to inform, to teach, to popularise scientific/technical notions, to argue), and the background knowledge assumed on the audience's part. They can also vary by frequency (Gotti 2005: 207-215). In genres addressed by experts to other experts, such as research articles, definitions are not frequent because terms are supposed to be known by receivers. In textbooks addressed to students and aimed at training prospective experts, many terms are introduced and definitions are frequent in order to illustrate the conceptual and terminological organisation within a given domain. In popular science publications, addressed to the interested reader, and in newspaper articles on specialised topics, addressed to the general public, the use of terms is limited and definitions are not so frequent.

Finally, definitions can vary by length and detail, and Werlich (1983: 70-78) draws a distinction between short and long definitions: the former extend over a short stretch of discourse, the latter can extend over one or more paragraphs and include detailed explanations, as in encyclopaedia entries and textbooks.

Scholars have suggested some classifications of definitions, e.g. Loffler-Laurian (1994) and Sager (1990: 39-54). Porcelli (2004), who has reviewed some of them, observes that 
they usually adopts a mix of formal (marker), semantic (method) and pragmatic (function) criteria. In our analysis, when examining method, we shall adopt the following typology as a working tool:

- definition by classification (when it mentions the class/category to which $\mathrm{X}$ belongs);

- definition by use/function (when it refers to what X can be used for);

- definition by description (when it describes some feature of X, e.g. its parts/components);

- definition by denomination (when it incorporates a process of denomination);

- definition by exemplification (when it provides examples of $\mathrm{X}$ );

- definition by synonymy (when it provides one or more synonyms of X).

Let us now see what can emerge in a cross-linguistic perspective, when comparing the pattern of definitions. Consider two statements taken from an English and an Italian encyclopaedia:

(5) Bradycardia, type of arrhythmia (abnormal heart rhythm) characterized by slowing of the heart rate to 60 beats per minute or less.

(6) Bradicardia, rallentamento del ritmo cardiaco al di sotto delle 60 pulsazioni al minuto.

In both languages, the term defined is printed in bold, the relater is a comma, and Y is constituted by a complex noun phrase. So the pattern is: $\mathrm{X}, \mathrm{Y}$ obtained by juxtaposition. When we examine another genre, the science popularisation article, we find statements like the following in Italian texts (the patterns are in italics):

(7) Per morte cardiaca improvvisa si intende la cessazione dell'attività cardiaca che avviene in una persona apparentemente sana.

(8) [...] un aminoacido (gli aminoacidi sono gli elementi-base che compongono le proteine.

The patterns in (7)-(8) are:

per $\mathrm{X}$ si intende $\mathrm{Y}$

$\mathrm{X}(\mathrm{Y})$

In (7), we find a complement containing the term, followed by the impersonal construction si + V (si intende), used as a detachment device and the periphrasis; in (8), a juxtaposition. 
Consider the following definitions from English articles:

(9) Sudden Death Syndrome is an umbrella term used for the many different causes of cardiac arrest in young people.

(10) Half of the patients were admitted to cardiology wards with 75 percent given a heart trace monitor test (echocardiogram)

The patterns in (9)-(10) are:

$\mathrm{X}$ is $\mathrm{Y}$

$\mathrm{Y}(\mathrm{X})$

In (9), the term is the subject of the clause; in (10), we observe a juxtaposition, where there is first the periphrasis, then the term.

In the examples above, (7) and (10) show quite distinct patterns, which are common in their respective languages. In (8) and (10), the mechanism is the same (juxtaposition), but the term occurs in two different positions.

\section{How to treat medical terms in PILs}

The issue of how to treat medical terms is discussed in some official documents. When providing guidelines on the readability of PILs, the European Commission (2009:9-10) recommends treating medical terms in the following way:

Medical terms should be translated into language that patients can understand. Consistency should be assured in how translations are explained by giving the lay term with a description first and the detailed medical term immediately after. On a case by case basis, the most appropriate term (lay or medical) may then be used thereafter throughout the leaflet in order to achieve a readable text.

The relevance of the definitions of medical terms as contributing to readability has been also stressed in the report published by MHRA (2005:31-53) in UK. In particular, the report observes that information about risk is often not well communicated to patients. Actually, the moves about risk are crowded with terms which often remain undefined. So the report provides guidance on risk communication: it suggests the use of simple words of few syllables and avoiding Latinate words, and an accurate description (and definition) of symptoms, by developing a consistent and clear glossary of lay words to employ instead of medical terms. In Annex 8 (MHRA 2005:123-128), there are a 
number of medical terms denoting symptoms and diseases with suggested lay words, for example:

$$
\begin{array}{ll}
\text { - anaemia } & \text { reduction in red blood cells } \\
\text { - angina pectoris } & \text { chest pain } \\
\text { - arrhythmia } & \text { irregular heart beat } \\
\text { - dyspepsia } & \text { indigestion } \\
\text { - myopathy } & \text { pain or weakness in muscles } \\
\text { - uveitis } & \text { inflammation of the eye which causes pain and redness }
\end{array}
$$

In Italy, AIFA (2004) observes that even if Italian PILs conform with European norms, most of them are not clearly comprehensible. The only document suggesting guidelines on readability —at the best of our knowledge-is an official paper of the Ministry of Health concerning non-prescription medicines only (Ministero della Salute 1997:6), where we read:

Il testo può essere modificato al fine di renderlo facilmente comprensibile dal paziente fornendo una spiegazione dei termini scientifici o specialistici utilizzati. Comunque, occorre aver cura di non omettere aspetti importanti anche se complessi. Non è accettabile, infatti, che siano riportate solo le informazioni relative agli eventi principali o più comuni. Infine, l'ipotesi che una informazione possa non essere compresa dal paziente non giustifica la sua omissione.

In other words, while recognising the need for defining medical terms, the document allows the use of specialist terms that may be not understood by patients when information is relevant.

Let us now consider the issue in linguistic and discursive terms. Being PILs a type of expert-to-layperson communication, two strategies can be adopted by the text producer: a) terminological simplification, achieved by replacing specialist terms with everyday vocabulary; b) definition of specialist terms expressed in a plain language.

Medical vocabulary consists of terms of Greek or Latin origins and eponyms that constitute a set of internationalisms (e.g. nefrite / nephritis, morbo di Crohn / Crohn's disease) and are usually semantically opaque to laypersons. The medical terms in PILs denote drugs, diseases, symptoms and organs, showing different levels of technicality. Following the classification of medical terms suggested by Serianni (2008: 258), five 
levels of technicality can be identified: 1) basic terms, familiar to laypersons; 2) terms familiar to educated lay readers; 3) terms used by all doctors; 4) terms used by most doctors; 5) terms used by specialists in the various areas of medicine. Terms with a (3) (5) level of technicality need to be defined, in particular in the central moves, such as “contraindications”, “possible side effects, etc., which provide relevant information for risk prevention.

\section{Analysing definitions}

\subsection{Corpus compilation and methodology}

The most suitable type of corpora for a contrastive study are comparable corpora, consisting of autonomous texts produced in two different cultures, but sharing a set of features (Pierini 2012:64-67). The comparable corpora were assembled by collecting Italian and British texts on the basis of similarity in their textual and contextual features - medium, genre, sender, communicative purpose, intended audience, communicative setting and content. The PILs were collected in two ways: the Italian leaflets as paper texts, and the British ones in an electronic version reproducing the original paper texts, by downloading them from the website http://www.medicines.org.uk/emc. Each corpus included 35 PILs of prescription medicines and 15 of non-prescription medicines ${ }^{4}$, belonging to a same set of pharmacotherapeutic groups and produced by both national (local) and multinational companies.

The texts were scanned manually and the definitions were analysed from a qualitative point of view by considering pattern and method, which can vary, while function (to explain the meaning of a term supposed to be unknown to receivers) is stable.

\footnotetext{
${ }^{4}$ The distinction between prescription and non-prescription medicines is valid in both UK and Italy. In Italy, non-prescription medicines are divided into two groups - farmaci su consiglio ('medicines on advice' (of pharmacists)), also called medicinali di automedicazione ('self-treatment medicines'), that cannot be displayed over the counter of the pharmacy, and farmaci da banco ('over-the-counter' medicines), which can be displayed over the counter and can be endorsed.
} 


\subsection{Analysis of data}

We shall now explore the definitions in the move 'pharmacotherapeutic group', where the medicine itself is defined, and in "contraindications", "possible side effects", "precautions for use” and “drug interactions”, which provide relevant information to prevent risk. The four moves were selected because there is wide recognition that risk communication problematises the reception of PILs (Fage-Butler, 2011), and clear definitions, when present, can contribute to improve readability.

In both languages, the definition of the medicine is by classification: the definiens is constituted by an hypernym of the definiendum, which identifies the class of entities.

The definitions of medicines in Italian leaflets accompanying prescription medicines show a restricted range of patterns (in italics) illustrated in the following examples:

(11) Cardiovasc appartiene a un gruppo di farmaci chiamati calcioantagonisti (derivati diidropiridinici).

(12) Neurontin appartiene a un gruppo di medicinali impiegati per il trattamento dell'epilessia e del dolore neuropatico periferico.

(13) (Cortison chemicetina) Categoria farmacoterapeutica: corticosteroidi deboli, associazioni con antibiotici.

(14) (OKi) Categoria farmacoterapeutica: antiinfiammatorio e antireumatico appartenente alla classe dei derivati dell'acido propionico.

(15) Augmentin è un antibiotico che funziona uccidendo i batteri che causano infezioni.

(16) Yasmin è una pillola contraccettiva e serve per prevenire la gravidanza.

The definitions in (11)-(14) make use of specialist terms, in particular (13)-(14), which do not mention the definiendum and define only for the expert. Definitions such as (15) and (16), which show a simple pattern (X è Y) and define in a plain language, occur in a limited number of texts.

The patterns found are three: two appear to be genre-specific, as the ones in (11)-(12) and in (13)-(14), the third pattern is less frequent:

$\mathrm{X}$ appartiene a un gruppo di farmaci/medicinali chiamati/impiegati

[X recoverable from the cotext] categoria farmacoterapeutica: Y

$\mathrm{X} \grave{e} \mathrm{Y}$ (hypernym) 
With regard to the method employed, the texts define primarily by classification (pharmaceutical category) and secondarily by use, as in (12) or denomination, as in (11).

The statements that follow are taken from leaflets accompanying non-prescription medicines:

(17) Multicentrum è un integratore alimentare multi-vitaminico - multi minerale con Luteina.

(18) Aspirina 03 è un analgesico (antidolorifico: riduce il dolore), antinfiammatorio e antipiretico (antifebbrile: riduce la febbre).

(19) Buscopan è un antispastico, anticolinergico, appartenente alla classe degli alcaloidi della belladonna semisintetici, composti ammonici quaternari.

They very frequently show the pattern:

$\mathrm{X} \grave{e} \mathrm{Y}$

and define by classification and/or use. (17) is taken from a leaflet accompanying OTC medicines, which try to offer less technical definitions, and are usually written in a plain language; (18)-(19), from leaflets accompanying 'on advice' medicines, show two different trends, like the ones accompanying prescription medicines: in (18), the terms introduced in $\mathrm{Y}$ are defined by juxtaposition, while in (19), $\mathrm{Y}$ is highly technical with many medical terms.

Let us now look at the definitions of medicines in the British leaflets:

(20) Sublimaze is one of a group of medicines known as opioid analgesics which relieve or prevent pain.

(21) Colofac is one of a group of medicines called antispasmodics, which are used in the treatment of irritable bowel syndrome (IBS).

(22) Nytol is an antihistamine which causes sleepiness or drowsiness and is used to help relieve temporary sleeping difficulties.

(23) Pharmaton Vitality Capsules are a multivitamin, mineral and ginseng supplement.

(24) Benylin Dry Coughs Non-Drowsy is a medicine which is used to help relieve dry, irritating coughs. 
(20) - (22) are taken from leaflets accompanying prescription medicines, and (23) - (24) from leaflets accompanying non-prescription medicines. The method of defining is by classification and use or denomination. The pattern found in both groups is

$\mathrm{X}$ is $\mathrm{Y}$ (one of a group of medicines known as/called, hypernym)

The two groups differ in two aspects. In (20)-(22), Y frequently includes the genrespecific expression one of a group of medicines. In (23)-(24), the definitions are simple, and make use of words belonging to general language. So, in English as well, two subtypes of leaflet can be identified, but the difference between them is less marked. The basic methods employed are by classification, classification and denomination, as in (21), or use, as in (24).

Our analysis goes on by considering the definitions of medical terms in the moves “contraindications”, “side effects”, “precautions for use” and “drug interactions”.

By scanning the leaflets of prescription medicines in the Italian corpus, we found that in about two-thirds of texts, the medical terms remain undefined. They are frequently of a medium/high level of technicality, as in (25)-(27), with terms referring, respectively, to drugs, organs and symptoms:

(25) La somministrazione di alte dosi di cianocobalamina per via parenterale può mascherare una eventuale deficienza di folati.

(26) Tegretol può scatenare reazioni di ipersensibilità, incluse reazioni di ipersensibilità a più organi che possono interessare la cute, il fegato (inclusi i dotti biliari introepatici), gli organi emopoietici [...]

(27) Con l'uso di paracetamolo sono state segnalate reazioni cutanee di vario tipo e gravità inclusi casi di eritema multiforme, sindrome di Stevens-Johnson e necrolisi epidermica.

About one-third of the texts is constituted by leaflets that try to simplify terminology and define the terms employed, as in (28)-(31):

(28) [...] se sta assumendo cimetidina (un farmaco per l'ulcera, l'indigestione o il bruciore di stomaco).

(29) [...] comporta per la donna un aumento del rischio di trombosi venosa (formazione di un coagulo nelle vene).

(30) [...] mughetto (candida, un'infezione da funghi della vagina, bocca o pieghe della pelle). 
(31) broncospasmo (respiro sibilante o respiro corto)

When considering the PILs accompanying non-prescription medicines, the leaflets accompanying OTC medicines try to use a plain language, but still make use of terms with a low level of technicality, as in (32), and definitions are absent:

(32) Il prodotto è sconsigliato nei soggetti asmatici e nelle persone allergiche ai salicilati.

In the leaflets accompanying 'on advice' medicines, we found two trends similar to the ones observed in the leaflets accompanying prescription medicines. There is a small group of texts where terms are defined, as in (33):

(33) Con l'uso del prodotto sono possibili reazioni locali o generali di ipersensibilità ai componenti (arrossamento, gonfiore, prurito).

Then, there is a larger group of texts containing terms of a medium or high level of technicality, and few or no definitions, in particular in the moves "contraindications" and "side effects":

(34) [...] eosinofilia associata all'epatotossicità indotta dal farmaco, nefrotossicità (nefrite tubulo-interstiziale allergica), ematuria (presenza di sangue nelle urine).

(35) Patologie dell'occhio: midriasi, turbe dell'accomodazione, aumento del tono oculare.

In (34), the definition of ematuria is found in a stretch of discourse containing other terms with a high level of technicality. In (35), the terms remain undefined.

The definitions, when present in the Italian texts, show the pattern:

$\mathrm{X}(\mathrm{Y})$

and the method is usually by description and use, rarely by exemplification, as in (33).

The British leaflets accompanying prescription medicines combine terminological simplification, illustrated in (36), and the definition of the medical terms employed, as in the following definitions of drugs in (37), symptoms and diseases in (38), and a body part in (39):

(36) a. Do not use cystopurin if you have kidney disease.

b. Some people may experience stomach irritation.

(37) a. beta-blockers, medicines used to slow down the heart

b. warfarin (used to prevent blood clotting) 
c. other medicines called neuroleptics, which are given before an operation to cause sedation.

d. barbiturates and benzodiazepines (medicines known as sleeping pills, tranquillisers or medicines for mental disorders)

(38) a. jaundice (yellow colouration of the skin, eyes or nail beds and greenishyellow colour of the urine)

b. inflammation of the intestine (ulcerative colitis or Crohn's disease)

(39) blood vessels (the pulmonary arteries)

The points that emerge from the data are the following: the definitions of drugs are usually by use, more rarely by denomination, as in (37c) and by synonymy, as in (37d) where the synonyms are lay words; the definitions of symptoms are by description. With regard to the patterns used, juxtaposition is generally employed:

$\mathrm{X}, \mathrm{Y}$ or $\mathrm{X}(\mathrm{Y})$

We found few cases where the definiens precedes the definendium, as in (38b) above.

The PILs accompanying non-prescription medicines are written in a language characterised by terminological simplification and the few terms employed are defined with the same methods as the ones in (37)-(39):

(40) chloranfenicol (a medicine used to treat bacterial infections)

(41) [...] if you suffered from hypercalcaemia (high level of calcium in the blood)

The data show that the leaflets accompanying prescription and non-prescription medicines only differ in one aspect: the latter exhibit a higher level of terminological simplification.

\section{Discussion}

Comparing Italian and British PILs we have noted some similarities which seem to be features characterising the genre in both languages. PILs are small texts and definitions are short and concise: they extend over a sentence in the move "pharmatherapeutic group" and part of sentence in the other moves examined. The second similarity is the use of different patterns when defining the medicine in the opening, and when defining medical terms in the other moves, where the juxtaposition of definiendum and definiens separated by a comma or parentheses is typically used. The third one is the method of 
defining — by classification (medicines), use (drugs), and description (symptoms and diseases). But there are also significant differences.

In the Italian corpus, characterized by variability in the use of medical terms and definitions, we have identified three trends. The first two trends concern both prescription medicines and 'on advice' medicines: about two-thirds of PILs show a technical exposition where most (if not all) terms remain undefined. Even when definitions are provided, they are not very helpful to readers because 'embedded' in a type of discourse that tends to be formal and technical. In many texts, there is the use of a technical vocabulary which is not always motivated by a specific denotational need, rather by the text producers' concern for formal register and their wish to differentiate medical language from general language. Consider three examples from the Italian corpus:

- assumere, move “interactions":

- Informare il medico o il farmacista se si è assunto qualsiasi altro medicinale, anche senza prescrizione medica.

- soggetti, move "precautions":

- È bene impiegare il prodotto solamente nei soggetti adulti.

- popolazione pediatrica, move “interactions” (subheading)

About one-third of texts tries to simplify terminology and defines the terms employed. The third trend has been observed in the leaflets accompanying OTC medicines: texts are usually written in a language that tries to be non-technical, and definitions are absent.

In the British corpus, the leaflets of both prescription and non-prescription medicines, show a general trend towards terminological simplification along with the definition of most medical terms. The difference between the two groups is that the leaflets accompanying non-prescription medicines contain a smaller number of terms and, consequently, of definitions.

We suggest three possible reasons why there is more technical vocabulary in use in the Italian texts, and definitions are not always easy to understand. First, there is an 'external' reason - the lack of up-to-date national guidelines on the readability of PILs for all types of medicines. Any decision about the level of technicality of discourse is left to pharmaceutical companies, many of which continue to produce leaflets that give 
priority to legal considerations over the users' need to receive clear information. Secondly, there is the general tendency of Italian medical discourse towards a formal register (Serianni 2005). As pointed out by Scarpa (2008:154-155, 195-196), when compared to English, Italian scientific discourse addressed to non-experts is characterised by a higher level of formality, abstractness and technicality, clearly reflected in the vocabulary employed. Medical discourse addressed to patients seem to exhibit this same rhetorical tendency observed in other genres (e.g. textbooks) and other domains. Thirdly, the difference in the treatment of medical terms point to different assumptions about the receivers' background knowledge. The intended receiver is the patient who is to be assumed as a layperson, but many Italians texts with their technicality seem to address doctors and pharmacists rather than patients. The PILs seem to imply the presence of a doctor or a pharmacist as mediator between the medicine and the patient. Conversely, British PILs establish a direct relationship with users.

\section{Conclusions}

The technicality of discourse in PILs may lead to potentially harmful outcomes, such as the patient's anxiety and lack of adherence to the proposed treatment. The definitions of medical terms can contribute to improve the readability of texts.

The type of definition largely depends on the intended audience: the less expert the audience, the greater the need for defining a term, the less technical the definition. We have seen that the need for clarity is insufficiently satisfied in about two-thirds of the Italian leaflets where terms remain undefined or definitions are not easy to understand. Yet, as shown by the set of readable leaflets that define terms systematically, it is possible to write user-friendly texts.

This study has two implications for this type of expert-to-layperson communication: national governments should draw up detailed guidelines on the readability of PILs, and pharmaceutical companies should contribute to design and write leaflets that allow patients to locate and comprehend relevant information, in particular in the moves aimed at preventing risk when taking a medicine. 
References

AIFA (Agenzia Italiana del Farmaco) (2004), "Il foglietto illustrativo: tra strumento comunicativo e documento regolatorio", BIF. Bollettino d'informazione sui farmaci, 3/4, 51-56, available at http://www.agenziafarmaco.gov.it/sites/default/files/bif040251.pdf [26/01/13]

Askehave, I. \& Zethsen K. (2003), “Communication Barriers in Public Discourse: the Patient Package Insert”, Document Design, 4/1, 22-41.

Bhatia, V. (2004), Worlds of Written Discourse, London/New York, Continuum.

Bernardini, C. - Ambrogi V. - Fardella G. - Perioli L. \& Grandolini G. (2001), “How to Improve the Readability of the Patient Package Leaflet: a Survey on the Use of Colour, Print Size and Layout”, Pharmacological Research, 43/5, 437-444.

Connor, U. - Ruiz-Garrido M.F. - Rozycki W. - Goering E. - Kinney E.D. \& Koehler J.M. (2008), "Patient-directed Medicine Labeling: Text Differences between the United States and Spain”, Communication \& Medicine, 5/2, 117-32.

Cassandro, M. (1994). “Aspetti sintattici e lessicali della lingua medica contemporanea”, in De Mauro T. (a cura di), Studi sul trattamento linguistico dell'informazione scientifica, Roma, Bulzoni,71-89.

Clerehan, R. - Buchbinder R. (2006), “Toward a More Valid Account of Functional Text Quality: The Case of the Patient Information Leaflet”, Text \& Talk, 26/1, 3968.

Darian, S. (1982), “The Role of Definitions in Scientific and Technical Writing: Forms, Functions and Properties”, in: Høedt, J. - Lundquist L. - Picht H. \& Qvistgaard J. (eds.), Pragmatics and LSP, Proceedings of the 3rd European Symposium on LSP, Copenhagen, Erhvervsøkonomisk Forlag, 27-48.

Fage-Butler, A. M. (2011), “The Discursive Construction of Risk and Trust in Patient Information Leaflets”, Hermes, 46, 61-73.

Garner, M. - Ning Z. \& Francis J. (2011), “A Framework for the Evaluation of Patient Information Leaflets”, Health Expectations, 15, 283-294.

Gotti, M. (2005), Investigating Specialised Discourse, Bern, Peter Lang.

Gotti, M. \& Salager Meyer F. (eds.) (2006), Advances in Medical Discourse Analysis: Oral and Written Contexts, Bern, Peter Lang.

EMA (2011a), CMDh Annotated QRD Template for MR/DC Procedures, available at: 
http://www.hma.eu/fileadmin/dateien/Human_Medicines/CMD_h_/Templates/QR D/CMDh_201_2005_Rev6_2011_08-Clean.pdf [28/01/13]

EMA (2011b), QR Convention to be followed for the EMA QRD Templates, available at: http://www.ema.europa.eu/htms/human/qrd/docs/convention.pdf [28/01/13]

European Commission (2009), Guideline on the Readability of the Labelling and Package Leaflet of Medicinal Products for Human Use, available at: http://ec.europa.eu/health/files/eudralex/vol-

2/c/2009_01_12_readability_guideline_final_en.pdf [30/01/13]

Hirsh, D. - Clerehan R. - Staples M. - Osborne R.H. \& Buchbinder R. (2009), "Patient Assessment of Medication Information Leaflets and Validation of the Evaluative Linguistic Framework (ELF)”, Patient Education \& Counseling, 77, 248-254.

Kenny, T. - Wilson R. - Purves I. - Clark J. - Newton L. - Newton D. \& Moseley D.(1998), “A PIL for every Ill? Patient Information Leaflets (PILs): A Review of Past, Present and Future Use”, Family Practice, 15/5: 471-479.

Loffler-Laurian, A. (1994), "Les définitions dans la vulgarisation scientifique”, in D. Candel (ed.), Français scientifique et technique et dictionnaire de langue, Paris, Didier Érudition, 93-112.

Maglie, R.B. (2009), Understanding the Language of Medicine, Roma, Aracne Editrice. medicines.org, http://www.medicines.org.uk/emc/ [last accessed 28/04/13]

MHRA (2005), Always Read The Leaflet. Getting the best information with every medicine, available at: http://www.mhra.gov.uk/home/groups/pla/documents/publication/con2018041.pdf [29/01/13]

Ministero della Salute (1997), “Medicinali di automedicazione: definizione, classificazione e modello di foglio illustrativo”, Circolare 16-10-1997 n. 13, available at: http://www.salute.gov.it/imgs/C_17_normativa_704_allegato.pdf [27/01/13]

Mortara Garavelli, B. (1988), “Tipologia dei testi”, in: Holtus, G. - Metzeltin M. \& Schmitt C. (Hrgs), Lexicon der Romanistischen Linguistik, Band IV, Tübingen, Niemeyer, 157-168.

Osimani, B. (2007), “The Epistemic Nature of Package Leaflet Information: a Contribution to the legal debate on the role of Packages Leaflets in Therapeutic Consent”, Medic 15.03.2007, 72-90, available at: 
http://www.academia.edu/970916/The_Epistemic_Nature_of_Package_Leaflet_In formation_a_Contribution_to_the_Legal_debate_on_the_role_of_Package_Leafle ts_in_Therapeutic_consent [03/02/13]

Pander Maat, H. \& Lentz L. (2010), “Improving the Usability of Patient Information Leaflets”, Patient Education and Counseling , 80/1, 113-119.

Pierini, P. (2012), Comparing Italian and English, second edition, fully revised and enlarged, Roma, Aracne Editrice.

Porcelli, G. (2004), “I processi del definire in prospettiva glottodidattica”, Rassegna Italiana di Linguistica Applicata, 1, 67-88.

prontuariofarmaceutico, http://www.prontuariofarmaceutico.it [26/01/13]

Puato, D. (2012), "Variabili linguistiche e comprensibilità nei foglietti illustrativi dei medicinali tedeschi e italiani”, Lingue e Linguaggi, 7, 89-116, available at: http://siba-ese.unisalento.it/index.php/linguelinguaggi/article/view/12360/11019 [08/02/13]

Sager, J.C. (1990), A Practical Course in Terminology Processing, Amsterdam/Philadelphia, John Benjamins.

Scarpa, F. (2008), La traduzione specializzata. Un approccio didattico professionale, seconda edizione, Milano, Hoepli.

Searle, J.R. (1975), “A Taxonomy of Illocutionary Acts”, in: Gunderson K. (ed.), Language, Mind and Knowledge, Minneapolis, University of Minnesota Press, 344-369.

Serianni, L. (2005), Un treno di sintomi. I medici e le parole: percorsi linguistici nel passato e nel presente, Milano, Garzanti.

Werlich, E. (1983), A Text Grammar of English, Heidelberg, Quelle \& Meyer.

Received: February 2, 2014

Accepted: June 21, 2015

Published: September 28, 2015 